\title{
The strategy of coping with stress and selected health-related behavioural patterns of demobilized battle participants
}

\section{Strategia radzenia sobie ze stresem i wybrane wzorce zachowań zdrowotnych u zdemobilizowanych uczestników akcji zbrojnych}

\author{
Jacek Wąsik¹, Dorota E. Ortenburger ${ }^{1}$, Olga Andriychuk ${ }^{2}$ \\ ${ }^{1}$ Department of Kinesiology and Health Prevention, Jan Dlugosz University, Częstochowa, Poland \\ Head of the Department: Jacek Wąsik PhD, Prof. JDU \\ ${ }^{2}$ Department of Health and Physical Therapy, Faculty of Physical Culture, Sport and Health, Lesya Ukrainka Eastern European National \\ University, Lutsk, Ukraine \\ Head of the Department: Prof. Olga Andriychuk
}

Medical Studies/Studia Medyczne 2020; 36 (2): 116-121

DOI: https://doi.org/10.5114/ms.2020.96791

Key words: stress, trauma, coping strategies, pain, rehabilitation, psychology.

Słowa kluczowe: stres, uraz, strategie radzenia sobie, ból, rehabilitacja, psychologia.

\begin{abstract}
Aim of the research: The aim of the research was to express knowledge of the role of ties (relations) between mental factors such as trust in one's own possibilities of coping with pain and availing of the active strategies of coping with stress, while also the degree of readiness to limit stress with the aid of the use of alcohol.

Material and methods: The research covered a group of 38 demobilized anti-terrorist operation (ATO) participants (men, 21-56 years) undergoing treatment and rehabilitation in the hospital. A measurement was conducted with the aid of certified psychological questionnaires and from medical documentation.

Results: A correlation was found between the active strategy of coping with the stress felt and the strategy of coping with pain of the internal control of pain (ICS) type - internal control of pain $(\mathrm{r}=0.71 ; p<0.05)$, as well as a negative correlation between the readiness to utilize stimulants with the aim of easing stress and the strategy of coping with pain of the ICS type $(r=-0.58 ; p<0.05)$.

Conclusions: The ways of coping with stress and pain by the hospitalized participants of combat action may be significant factors (of a psychological nature) that have an impact on their readiness to undertake behaviour that is significant for their health (such as alcohol and others) with the aim of reducing the symptoms of nervous tension felt.
\end{abstract}

\section{Streszczenie}

Cel pracy: Zwiększenie wiedzy na temat roli powiązań (relacji) między czynnikami psychologicznymi, takimi jak zaufanie do własnych możliwości radzenia sobie z bólem i korzystanie z aktywnych strategii radzenia sobie ze stresem, a stopniem gotowości do ograniczania skutków odczuwanego stresu za pomocą spożywania alkoholu.

Materiał i metody: Badaniami objęto grupę 38 zdemobilizowanych uczestników operacji antyterrorystycznej (ATO) (mężczyźni: 21-56 lat) poddawanych leczeniu i rehabilitacji w szpitalu. Pomiar przeprowadzono za pomocą certyfikowanego kwestionariusza psychologicznego i danych pochodzących z dokumentacji medycznej.

Wyniki: Stwierdzono, że występuje korelacja między aktywną strategią radzenia sobie z odczuwanym stresem a strategią radzenia sobie z bólem opartą na wewnętrznej kontroli bólu (ICS) $(r=0,71 ; p<0,05)$, a także zaobserwowano ujemną korelację między gotowością do użycia stymulantów w celu złagodzenia odczuwanego stresu a strategią radzenia sobie z bólem typu ICS $(r=-0,58 ; p<0,05)$.

Wnioski: Sposoby radzenia sobie ze stresem i bólem przez hospitalizowanych uczestników akcji bojowej mogą odgrywać znaczącą rolę jako czynniki (o charakterze psychologicznym) potencjalnie wpływające na gotowość do podjęcia istotnych dla zdrowia zachowań (takich jak spożywanie alkoholu i innych) w celu zmniejszenia objawów odczuwanego napięcia nerwowego. 


\section{Introduction}

The participants of combat action with relation to the tasks executed are exposed to experiencing traumatic events. This is first and foremost connected with the possibility of endangering health, while also confrontation with their own deaths and the deaths of other people. Such people face extraordinarily difficult challenges such as continuing actions aimed at the achievement of the stipulated aims in situations of intensive stress. Such events bring multiple negative consequences in the sphere of mental and physical health. They may be a source of anxiety, unease, insomnia, irritability and anger, symptoms of depression, or becoming involved in behaviour that is not beneficial to their health, such as, among other things, the intensive use of alcohol [1].

Several types of strategies of coping with strong nervous tension and its repercussions are distinguished. These are as follows: active coping with stress (planning possible actions, searching for various possibilities of help, positive re-evaluation), helplessness (use of psychoactive substances, alcohol, ceasing of remedial action), searching for support (emotional and instrumental), avoidance behaviour (including: dealing with something else, denial, venting emotion) [2].

The ability to cope with stress is a significant part of the processes of self-regulation and the skill of adjusting the strategies of procedure to the requirements of the situation which a person is facing. This is also strongly individualized, which is illustrated by both scientific research and casual observations that highlight how people differ from each other [3].

Using alcohol (or other stimulants) with the aim of easing the effects of experiences of a traumatic nature constitutes a problem for a multitude of people who are involved in actions that endanger their safety, to a large extent soldiers and non-professional veterans of combat action [4]. Searching for relief and improvement of self-esteem by means of alcohol is treated as a non-constructive strategy in easing the psychophysiological effects of stress, which improves selfesteem only for a brief period, after which it deepens the existing health, financial and social problems [5]. It is a source of problems over a long-term perspective as these phenomena may occur in interactions based on feedback, e.g. the abuse of alcohol may lead to conflicts - and conflicts increase exasperation, irritability and anger.

Some researchers note that not only soldiers but also other groups face the consequences of posttraumatic stress. The occurrence of similar mental consequences have been noted in a group of medical rescuers, which is confirmed by research conducted in several countries [6]. Approximately half of British rescuers experienced intrusive thoughts, feelings of irritation, problems with sleeping and distancing themselves from other people [2]. Research conduct- ed by Polish researchers indicates that almost half of them felt the impact of traumatic experiences in their professional lives and family lives. Simultaneously, the majority of medical rescuers analysed admit that extreme stress during rescue missions does not overcome their possibilities of adaptation and does not cause a reduction in their readiness to participate in future rescue missions [6]. This problematic issue is developed intensively, which is expressed by the currently conducted research on the strategies of coping with stress among groups of medical students, while also during the first clinical practice [7]. There are reports that illustrate the intricate relations between the patient-related stressors and coping strategies in baccalaureate nursing students during clinical practice [8]. The current and past conflicts have resulted in a large group of military participants exposed to combat-related psychological trauma. In the literature the long-term effects of both types of trauma have been viewed as having different neural substrates, but long term research shows that the chronic effects of exposure to either process (psychical and physical trauma) are associated with a large, significant overlap in many clinical symptoms. Investigations into the relation between stress and trauma pathophysiology have focused on excessive activation of the amygdala and altered response to acute and chronic stress [9]. The experiences of the soldiers may lead to a crisis: behaviour disorganisation, psychosomatic, and psychopathological disorders [10].

The participants of combat action are frequently exposed to pain. Coping with pain and its consequences are of significance for our state of health [11]. Pain belongs to the strong stressors, in which the following components permeate: sensory, affective, motivational, cognitive $[1,12]$. Research illustrates that in terms of people who want to reduce the unpleasant experiences, there is a risk of developing an addiction $[4,6]$. The relation between health and coping with long-term stress and pain is widely analysed and widely documented in psychoneuroimmunology $[13,14]$.

In accordance with the holistic paradigm that underlies psychoneuroimmunology, pain connects the physical and mental experiences, which have a reciprocal impact on each other. People who are unable to deal with stress feel the acute effects of chronic pain and those who as a result of psycho-physical overload develop symptoms of depression [15]. Hence, the abuse of, for instance, alcohol during feelings of helplessness may constitute a way to change the state of awareness with the aim of reducing the feeling of pain which ultimately makes depression more profound.

The differences in terms of attitudes towards pain (from complete helplessness to various types of feelings of effectiveness) are visible in the form of convictions - W (trust in personal management), L (faith in medical care), P (conviction about the case) [3]. These differences are particularly visible in situations of ex- 
periencing pressure, whose extreme example is participation in combat action.

Participation in this type of action, as well as the injuries incurred, leads to the fact that the adjustment of the soldier to normal everyday life constitutes a challenge. A person in such situations instigates behaviour that is directed at coping with the consequences of traumatic events. Hence, it is important to become familiar with the relations and dependencies of the strategies of coping with stress and pain with the aim of preparing therapeutic programmes. In relation to this fact, an attempt at an analysis was undertaken as to whether the specified type of strategies of coping with stress and pain are associated with the use of stimulants (primarily alcohol) among the group of hospitalized participants of combat action.

With regard to this fact, we concentrated on becoming familiar with the relations between the following:

1) strategy of coping with pain type "W", while releasing stress by means of various stimulants;

2) availing of active constructive remedial strategies that are aimed at reducing the symptoms of nervous tension and the frequency of using alcohol;

3) strategies of coping with pain in patients and their diagnosis in the sphere of the basis of the ailments experienced.

\section{Aim of the research}

The following hypothesis was put forward: trust in one's own possibilities to cope with stress and the use of active strategies to cope with stress are associated with a lower consumption of alcohol.

\section{Material and methods}

\section{Subjects}

The research covered a group of 38 demobilized anti-terrorist operation (ATO) participants, only men, undergoing treatment and rehabilitation in the hospital aged between 21 and 56 years (34.48 \pm 8.91 years). The causes of hospitalization in $66 \%$ of cases were wounds in the combat area, and in 34\% deterioration of chronic diseases or chronic pathological changes. Duration of service and residence stay in conflict zone: 1-6 months. A measurement was conducted with the aid of certified psychological questionnaires (Beliefs About Pain Control Questionnaire and Mini-Cope Inventory). Additional, medical data relating to the analysed people, including the state of health of the patients, were acquired from medical documentation.

\section{Protocol}

A measurement was conducted with the aid of certified psychological questionnaires: Beliefs About Pain Control Questionnaire - BPCQ [16]. Data relating to mental functioning were acquired by the appli- cation of the Mini-Cope Inventory, which constitutes a fully-fledged standardized version [17]. A shorter version of Cope (The Coping Orientations to Problems Experienced) was applied due to the reactions of those under analysis, who displayed exasperation and a reluctance towards time-consuming completion of expanded questionnaires. Additional information referring to the analysed people in the state of health of patients was acquired via medical documentation. These data encompassed a diagnosis of the type of pain that occurs in patients with particular attention paid to whether the pain experienced had features of neuropathic pain.

The research includes human data. It has been performed in accordance with the Declaration of Helsinki and has been approved by the Lesya Ukrainka Eastern European National University, Lutsk, Ukraine Bioethics Commission (no. 2/2018). Before interviews, the nature and the purpose of the study were explained, and full confidentiality was assured to all participants. All participants were informed about their right not to participate in the study and gave their oral consent before the study.

\section{Statistical analysis}

Analysis was conducted on the regression between the use of stimulants by soldiers (dependent variable) and two dependent variables (active strategy of coping with stress and the type of conviction defined as: "Internal control of pain". In the conducted research for all the registered indexes, the mean (M) and standard deviation (SD) were specified. For the statistical analyses, the value of $\alpha=0.05$ was considered as significant. All calculations were performed using Statistica 12.00 .

\section{Results}

In Figure 1, a graphic interpretation is presented of the dependencies between three chosen variables: the application of the active strategy of coping with stress (ACS), coping with pain of the type internal control of pain (ICP), as well as the readiness to consume alcohol as an antidote for nervous tension (ACS). In Table 1, the values of the coefficient correlations of the same variables are illustrated. Table 2 contains the average values of the distribution of data relating to the intensity of the particular types of convictions regarding the control of pain; according to the criteria: 1) the existence of neuropathic pain, 2) pain of a mixed nature - probably (not fully confirmed) damage to the nerve underlying chronic pain, 3) lack of neuropathic pain.

\section{Discussion}

The acquired results indicate that the group of hospitalized participants of anti-terrorist action encompassed within the research, who are people of 
a lower value of the ICP indicator and who do not avail of the active strategies, may be more susceptible to "escaping to alcohol" (Figure 1).

It was revealed that a correlation $(r=0.71 ; p<0.01)$ exists between the active strategy of coping with the stress experienced (ASS) and the strategy of coping with pain of the ICP type.

This provides the argument which is supportive of the view that the analysed people who learnt to cope with various forms of stress themselves are "vaccinated" against other factors that evoke a stressful reaction, i.e. pain. At the basis of this covariance there may be a more profound neurophysiological mechanism that is described on the basis of the theory of the Gate Control Theory.

In accordance with the concept entitled "Gate Control Theory," the response to the unpleasant stimulants depends not only on the nature of the stimulant, but also to a large extent on the individual features of the nervous system of the particular person [1]. At a psychological level, this may signify that the basis of coping with stress and pain may involve a common feature which is defined as "proactivity" in the sphere of individual responses to situations that arouse anxieties in a person, which may be indicated by the results of previous research [18].

Active coping with stress is indicated by a moderate correlation $(r=-0.37 ; p<0.01)$ with the willingness to consume alcohol (and use of other stimulants) with the aim of easing stress. However, we do not know how many people indicated a tendency to consume alcohol prior to conscription and how many developed this tendency during military service, or in the aftermath of defence action. On the basis of the present research, we may merely state that we have noted covariance (a negative sign of correlation) between active strategies and readiness to reach out for alcohol as a way to reduce the unpleasant symptoms of excessive nervous tension.

The lower tendency towards the consumption of alcohol co-exists with the greater conviction that it is possible to restrict the experienced pain effectively by

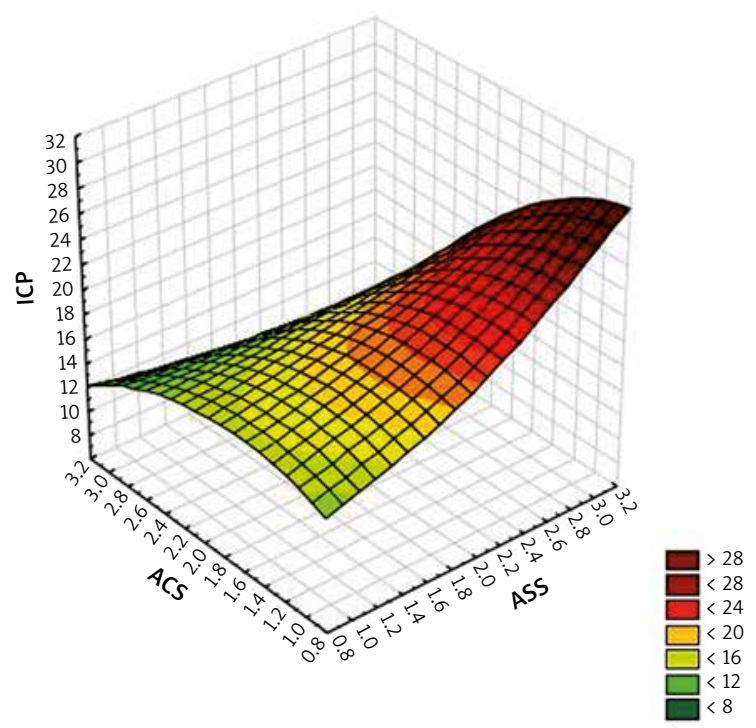

Figure 1. Graphic presentation of dependency between three variables analysed: active strategy coping with stress (ASS), internal control of pain (ICP), alcohol coping strategy (ACS)

Table 1. Table of correlations between chosen variables $(p<0.05)$

\begin{tabular}{|lccc|}
\hline Variable & ASS & ICP & ACS \\
ASS & - & 0.71 & -0.37 \\
ICP & 0.71 & - & -0.58 \\
ACS & -0.37 & -0.58 & - \\
\hline
\end{tabular}

ASS - active strategy coping with stress, ICP-internal control of pain, ACS - alcohol coping strategy.

oneself $(r=-0.58, p<0.01$, as well as a higher level of activity of coping with stress $(r=-0.37, p<0.01)$. It is worth noting that in the case where the acquired results illustrated a contrasting tendency, namely, if the increase in the readiness to consume alcohol as a remedial action for stress is accompanied by growth in the value of the variable of "active coping with stress",

Table 2. Average values of distribution of data relating to the intensification of particular types of convictions with regard to controlling pain (in scores)

\begin{tabular}{|c|c|c|c|c|c|c|c|}
\hline \multirow[t]{2}{*}{ No. } & \multirow[t]{2}{*}{ Nature (type) of pain } & \multicolumn{2}{|c|}{ ICP } & \multicolumn{2}{|c|}{ DCP } & \multicolumn{2}{|c|}{ PCE } \\
\hline & & $M$ & SD & $M$ & SD & $M$ & SD \\
\hline 1 & $\begin{array}{l}\text { Neuropathic pain. Confirmed damage to the nerve underlying } \\
\text { chronic pain }\end{array}$ & 16.17 & 2.31 & 12.72 & 2.91 & 13.17 & 3.50 \\
\hline 2 & $\begin{array}{l}\text { Pain of a mixed nature. Not fully confirmed (probable) } \\
\text { damage to nerve underlying chronic pain }\end{array}$ & 20.79 & 2.35 & 12.74 & 4.53 & 13.58 & 3.12 \\
\hline \multirow[t]{2}{*}{3} & $\begin{array}{c}\text { Lack of pain of a neuropathic nature (lack of confirmation of } \\
\text { damage to nerve) }\end{array}$ & 24.91 & 3.75 & 12.91 & 6.47 & 14.36 & 3.98 \\
\hline & Total number of patients & 20.00 & 4.31 & 12.77 & 4.45 & 13.60 & 3.43 \\
\hline
\end{tabular}

$M-$ mean, $S D$ - standard deviation. 
this could certify the fact that behaviour involving the consumption of alcohol is treated by the analysed people as their own "actions" (alternate). This would also find clarification in the light of subject-related literature, in which there is mention of the phenomenon that exists in people, namely, "the illusions that enable them to live peacefully". Health psychology describes these types of mechanisms involving selfdeceit in broader terms [19].

The data presented in Table 2 illustrate that patients differ with regard to diagnosis in relation to the presence of neuropathic pain. This indicates that the level of trust in one's own possibilities in the sphere of coping in the case of the feeling of pain turns out to be an issue that requires greater attention in the situation in which among the hospitalized soldiers where pain occurred, it accompanied injuries associated with damage to nerves (neuropathic pain). Neuropathic pain leads to the situation where the therapy is long-lasting and less efficient than the treatment of other types of pain [17]. This results from its specifics and the duration.

Pain of a neuropathic nature, which emerges as a result of damage to a nerve or its sheath, may involve many years of healing in terms of the tissue, which evokes negative emotions $[20,21]$. Due to the increasing difficulty in the active constructive coping in terms of the situation of pressure, in this group there may be an increased level of risk of the use of stimulants with the aim of reducing the unpleasant symptoms of excessive nervous tension (irritability, frustration) [20, $22,23]$. The results presented are encouraging in terms of continuing the research in its current form.

The acquired data illustrate that the applied method may have practical application in terms of screening and prophylactic tests, as well as the evaluation of the effectiveness of the therapy [16]. We are of the opinion that following the conclusion of the therapy for the hospitalized participants of combat action, it is justifiable to conduct similar research with the aid of the same methods. This would provide information about the effectiveness of the therapeutic impact. The acquired data provide arguments in order to take account of the psychological aspect in a broader sense in terms of the possible therapeutic effects during the course of medical rehabilitation for veterans of combat action. This is illustrated by the research results of a wide section of the research programme which encompassed the participants of ATO actions [24, 25]. Analysis of subject-related literature in a psychological sphere in terms of the circumstances of mental stress and trauma illustrates that the various aspects of the functioning of patients who participated in combat action should be perceived in the context of the mutual ties between the somatic factors and the factors of psychological and social spheres. The negative impact of war on mental health has been repeat- edly documented. The ties between the variables from the particular areas of the functioning of an individual may indirectly modify the negative consequences of the experiences suffered, such as participation in combat action $[26,27]$.

The conclusions presented do not fully exhaust the subject matter covered, although the accumulated data relating to the health behaviour of the participants of combat action under analysis, and also their ways of coping with stress, facilitate the cautious formulation of the fundamental conclusions. A limitation for our tests was the wide range of age groups of the participants presented in the research. The people under analysis were participants of military defence action who were not selected with regard to age. In this research there was an insufficient number of people of various age groups; thus we could not focus on a dependency, albeit an interesting one: age and coping with stress.

\section{Conclusions}

The observed results suggest that the active strategy of coping with stress and internal control of coping with pain is indicated by a moderate negative correlation with the willingness to consume alcohol. Research has confirmed the existence of a relation between the strategies of coping with stress and the health behaviour of the participants of combat action. The expression (representative symptom) of these ties is, among others, the occurrence of the correlation (of an additional sign) between an active strategy of coping with stress and the strategy of coping with pain.

The ways of coping with stress and pain on the part of the hospitalized participants of combat action may be factors (psychological independent variables) that potentially influence the readiness to undertake behaviour that is significant for their health (such as use of alcohol, etc.) with the aim of reducing the symptoms of nervous tension experienced. This is backed up by the acquired results that indicate covariance (negative) between the level of trust in their own possibilities of coping with pain and the readiness to use alcohol as a strategy for easing the effects of stress. A negative correlation was also noted between the degree of using active strategies of coping with stress and the readiness to use alcohol. With regard to the fact that undertaking constructive ways of coping with the mental effects of traumatic experiences increases the chances of recovering, it is worth taking these results into account, particularly during the course of preparing programmes for patients who have incurred damage to their health during combat action and who do not indicate psychologically active remedial action.

\section{Conflict of interest}

The authors declare no conflict of interest. 


\section{References}

1. Melzack R. Pain and the neuromatrix in the brain. J Dent Educ 2001; 65: 1378-1382.

2. Carver CS, Scheier MF. Weintraub JK. Assessing coping strategies: a theoretically based approach. J Pers Soc Psychol 1989; 56: 267-283

3. Strong J, Ashton R, Chant D. The measurement of attitudes towards and beliefs about pain. Pain 1992; 48: 227236.

4. Williams JL, McDevitt-Murphy ME, Murphy JG, Crouse EM. Deployment risk factors and postdeployment health profiles associated with traumatic brain injury in heavy drinking veterans. Mil Med 2012; 177: 789-796.

5. Sheridan CL, Radmacher SA. Health Psychology: Challenging the Biomedical Model, International Edition, John Wiley and Sons, United Kingdom 1992.

6. Oginska-Bulik N. Negative and positive effects of traumatic experiences in a group of emergency workers the role of personal and social resources. Med Pracy 2013; 64: 463-472.

7. Bodys-Cupak I, Grochowska A, Zalewska-Puchała J, Majda A. Stress and coping strategies of medical students during their first clinical practice - a pilot study. Med Stud 2019; 35: 294-303.

8. Bodys-Cupak I, Majda A, Grochowska A, Zalewska-Puchała J, Kamińska A, Kuzera G. Patient-related stressors and coping strategies in baccalaureate nursing students during clinical practice. Med Stud 2019; 35: 41-47.

9. McAllister TW, Stein MB. Effects of psychological and biomechanical trauma on brain and behavior. Ann N Y Acad Sci 2010; 1208: 46-57.

10. Iversen AC, Neil Greenberg N. Mental health of regular and reserve military veterans. Adv Psychiatr Treatment 2009; 15: 100-106.

11. Villemure C, Bushnell MC. Cognitive modulation of pain: how do attention and emotion influence pain processing? Pain 2002; 95: 195-199.

12. Strong J, Ashton R, Chant D. The measurement of attitudes towards and beliefs about pain. Pain 1999; 48: 227-236.

13. Dunn AJ, Wang J, Ando T. Effects of cytokines on cerebral neurotransmission. Comparison with the effects of stress. Adv Exp Med Biol 1999; 461: 117-127.

14. Schleifer SJ, Marbach J, Keller SE. Psychoneuroimmunology: potential relevance to chronic orofacial pain. Anesthesia Progress 1990; 37: 93-98.

15. Brian L. Stress, depression and the activation of the immune system. World J Biol Psychol 2000; 1: 17-25.

16. Skevington SM. A standardized scale to measure beliefs about controlling pain (BPCQ): a preliminary study. Psychol Health 1990; 4: 221-232.

17. Carver CS. You want to measure coping but your protocol's too long: consider the brief COPE. Int J Behav Med 1997; 4: 92-100.

18. Proios I, Batsiou S, Proios M. Volition profile of people with physical disability. Phys Activ Rev 2018; 6: 151-160.

19. Taylor SE, Armor DA. Positive illusions and coping with adversity. J Pers 1996; 64: 873-898.

20. Egli M, Koob, GF, Edwards S. Alcohol dependence as a chronic pain disorder. Neurosci Biobehav Rev 2012; 36: 2179-2192.

21. Zale EL, Maisto SA. Ditre JW. Interrelations between pain and alcohol: an integrative review. Clin Psychol Rev 2015; 37: 57-71.
22. Ortenburger D, Rodziewicz-Gruhn J, Wasik J, Marfina $\mathrm{O}$ Polina N. Selected problems of the relation between pain-immunity and depression. Phys Activ Rev 2017; 5: 74-77.

23. Lubkowska W, Krzepota J. Quality of life and health behaviours of patients with low back pain. Phys Activ Rev 2019; 7: 182-192.

24. Ortenburger D, Wąsik J, Tsos A, Andrijchuk O, Bielikowa N, Indyka S. Selected aspects of the health condition of hospitalised soldiers after military action and the manifestation of externalising anger. Med Stud 2019; 35: 288-293.

25. Grygus I. The role of physical activity in the rehabilitation of patients suffering from mild persistent bronchial asthma. Phys Activ Rev 2017; 5: 155-166.

26. Wooten NR, Brittingham JA, Pitner RO, Tavakoli AS, Jeffery DD, Haddock KS. Purchased behavioral health care received by military health system beneficiaries in civilian medical facilities, 2000-2014. Mil Med 2018; 183: e278-e290.

27. Sogabe A. Influence of difference in knee alignment on site of pain and psychological state after long-distance walking. Phys Activ Rev 2013; 1: 1-9.

\section{Address for correspondence:}

Prof. Jacek Wąsik

Department of Kinesiology and Health Prevention

Jan Dlugosz University

ul. Waszyngtona $4 / 8$,

42-200 Częstochowa, Poland

Phone: +48 503053142

E-mail: j.wasik@ajd.czest.pl 